\title{
The role of bile acids in metabolic regulation
}

\author{
Libor Vítek ${ }^{1,2}$ and Martin Haluzík ${ }^{2,3}$ \\ ${ }^{1}$ Fourth Department of Internal Medicine, First Faculty of Medicine, Charles University, Na Bojišti 3, Prague 2 12000, \\ Czech Republic \\ ${ }^{2}$ Institute of Medical Biochemistry and Laboratory Diagnostics, First Faculty of Medicine, Charles University, Prague, \\ Czech Republic \\ ${ }^{3}$ Institute of Endocrinology, Charles University, Prague, Czech Republic
}

\begin{abstract}
Bile acids (BA), long believed to only have lipid-digestive functions, have emerged as novel metabolic modulators. They have important endocrine effects through multiple cytoplasmic as well as nuclear receptors in various organs and tissues. BA affect multiple functions to control energy homeostasis, as well as glucose and lipid metabolism, predominantly by activating the nuclear farnesoid X receptor and the cytoplasmic $G$ protein-coupled BA receptor TGR5 in a variety of tissues. However, BA also are aimed at many other cellular targets in a wide array of organs and cell compartments. Their role in the pathogenesis of diabetes, obesity and other 'diseases of civilization' becomes even more clear. They also interact with the gut microbiome, with important clinical implications, further extending the complexity of their biological functions. Therefore, it is not surprising that BA metabolism is substantially modulated by bariatric surgery, a phenomenon contributing favorably to the therapeutic effects of these surgical procedures. Based on these data, several therapeutic approaches to ameliorate obesity and diabetes have been proposed to affect the cellular targets of BA.
\end{abstract}

Correspondence should be addresses to L Vítek Email

vitek@cesnet.cz

\section{Introduction}

Bile acids (BA), which for decades were considered to only be involved in lipid digestion in the intestinal lumen and cholesterol solubilization in the bile, now seem to have pleiotropic effects: contributing to the homeostasis of lipids, glucose and other metabolic substrates (Li \& Chiang 2014, Qi et al. 2015), affecting immune system functions (Sipka \& Bruckner 2014) as well as gut microbiome composition (Ridlon et al. 2014). By binding to multiple cytoplasmic as well as nuclear receptors in various organs and tissues, they act as real hormones. Based on these facts, a paradigm for BA endocrine functions has recently been postulated (Houten et al. 2006).

\section{Bile acid metabolism}

BA are amphiphilic molecules derived from cholesterol in the hepatocytes. The principal metabolic changes are comprised of shortening of the cholesterol side chain plus hydroxylation of the core of the molecule at specific carbon atoms, forming the primary BA, cholic acid and chenodeoxycholic acid respectively (Hofmann 1984). These primary BA, after conjugation with glycine or taurine in the liver, are actively secreted into the bile via the bile salt export pump (BSEP, ABCB11, OMIM *603201). The BA pool in the human body is maintained by the efficient enterohepatic circulation (Hofmann 1984), preserving as much as $95 \%$ of conjugated BA. The active reabsorption of conjugated BA occurs in the distal ileum through the ASBT (also known as ISBT/IBAT/NTCP2, OMIM *601295) (Modica et al. 2010), and is profoundly deteriorated by inflammatory conditions affecting the ileal mucosa, such as in Crohn's disease (Lenicek et al. 2011, Vitek 2015). Unconjugated BA, formed after glycine/taurine hydrolysis by intestinal bacteria, can also

Published by Bioscientifica Ltd. 
be absorbed by passive diffusion from both the small and large intestine; however, their transport is much less effective via this route. The so-called 'BA gut-liver axis' is regulated by the farnesoid $X$ receptor (FXR), the intracellular BA sensor. In the ileocytes, FXR controls for BA uptake, their intracellular trafficking as well as BA basolateral efflux (mediated by organic solute transporters $\alpha / \beta($ OST $\alpha / \beta)$ ) (Zwicker \& Agellon 2013). Simultaneously, ileal enterocytes, upon stimulation of FXR with BA, also secrete FGF19, which downregulates BA synthesis in the hepatocytes (Holt et al. 2003). However, FGF19 secreted from the small intestine in response to feeding also has insulin-like functions, whereas FGF21, a counterpart to FGF19, secreted from the liver in response to prolonged fasting, has glucagon-like effects (Potthoff et al. 2012). In fact, while insulin/glucagon serve as immediately acting fed-state and fasted-state hormones, FGF19 and FGF21 can be considered late-acting hormones (Potthoff et al. 2012). Interestingly, when administered in pharmacological doses, both FGF19 and FGF21 have insulin-sensitizing and hypolipidemic effects in rodent models of obesity and type 2 diabetes (T2DM) (Tomlinson et al. 2002, Kharitonenkov et al. 2005).

Apart from the FGF19 signaling pathway, hepatic BA synthesis is also controlled by another FXR-dependent mechanism, which is the small heterodimer partner (SHP, another orphan nuclear receptor) mediated downregulation of the CYP7A1 gene, coding for cholesterol $7 \alpha$ hydroxylase, the rate-limiting enzyme in BA synthesis from cholesterol (Chiang 2009). In addition to this important function, SHP serves as a versatile corepressor of gene expression by inhibiting numerous transcriptional factors in diverse metabolic, proliferative and inflammatory pathways (Seok et al. 2013).

\section{Cellular targets of BA}

The emerging role of $\mathrm{BA}$ in various metabolic processes is mediated through several membrane and nuclear receptors (Zhou \& Hylemon 2014). These involve specific nuclear receptors. Apart from FXR, there are also vitamin $\mathrm{D}$ receptor (VDR), constitutive androstane receptor (CAR), pregnane $\mathrm{X}$ receptor (PXR) as well as the cytoplasmic receptors TGR5, muscarinic receptors and sphingosine 1-phosphate receptor 2 (S1PR2) (Table 1).

FXR, in addition to its essential role in cholesterol/BA metabolism, also contributes to triacylglycerol (Fuchs et al. 2013) and glucose metabolism. In fact, BA, via activation of FXR present in pancreatic $\beta$ cells, are capable of stimulating insulin production (Schittenhelm et al.
2015). Furthermore, FXR is also involved in the control of glucose homeostasis via its direct interaction with carbohydrate-responsive element-binding protein (ChREBP) acting as an important transcription factor of glycolytic genes (Benhamed et al. 2014). Surprisingly, FXR is also expressed in cardiovascular organs such as the heart and arterial system including coronary arteries, aorta as well as atherosclerotic arteries (Bishop-Bailey et al. 2004). The same is also true for the expression of VDR (Mathew et al. 2008) and PXR (Wang et al. 2013), pointing to the complexity of BA action on various organs and systems.

Although the role of PXR (another intracellular BA sensor in the pathogenesis of obesity and other metabolic disorders) awaits definite clarification, its effect on energy metabolism has been proven (Gao \& Xie 2012). Interestingly, PXR is also involved in the modulation of the innate immunity system. This is demonstrated even in vascular cells, protecting them against the harmful effects of xenobiotics (Wang et al. 2014).

CAR, originally reported as a nuclear receptor regulating the response to xenobiotics, is another nuclear receptor activated by BA (Zhang et al. 2004, Huang et al. 2006, Sipka \& Bruckner 2014). It is interesting to note that CAR has been marked as an anti-obesity nuclear receptor improving insulin sensitivity (Gao et al. 2009) as well as lipid metabolism (Maglich et al. 2009) and thyroid functions (Maglich et al. 2004).

TGR5 (GPBAR1), a member of the rhodopsin-like subfamily of $G$ protein-coupled receptors, is expressed in the enteroendocrine small-intestinal cells as well as in the thyroid gland, brown adipose tissue (Zhou \& Hylemon 2014), macrophages (Perino et al. 2014) and in many other organs (Duboc et al. 2014). An increasing body of evidence shows TGR5's important role in energy homeostasis, glucose metabolism (Thomas et al. 2009) and the modulation of immune functions (Perino et al. 2014). In addition, recently published data also demonstrated TGR5 expression in pancreatic $\beta$ cells, with a direct effect on insulin secretion (Kumar et al. 2012) (in a similar manner as described above for FXR) and also in cardiomyocytes (Desai et al. 2010).

BA have also been reported to activate specific muscarinic receptors (Raufman et al. 2003). Although this phenomenon has primarily been discussed in relationship to possible gastrointestinal pathologies (Zhou \& Hylemon 2014), stimulation of muscarinic receptors in endothelial cells has been shown to attenuate atherosclerosis in an experimental animal model (Zhou et al. 2014). Furthermore, muscarinic M3 receptors are also expressed in the adipose tissue (Yang et al. 2009) as well as

Published by Bioscientifica Ltd 

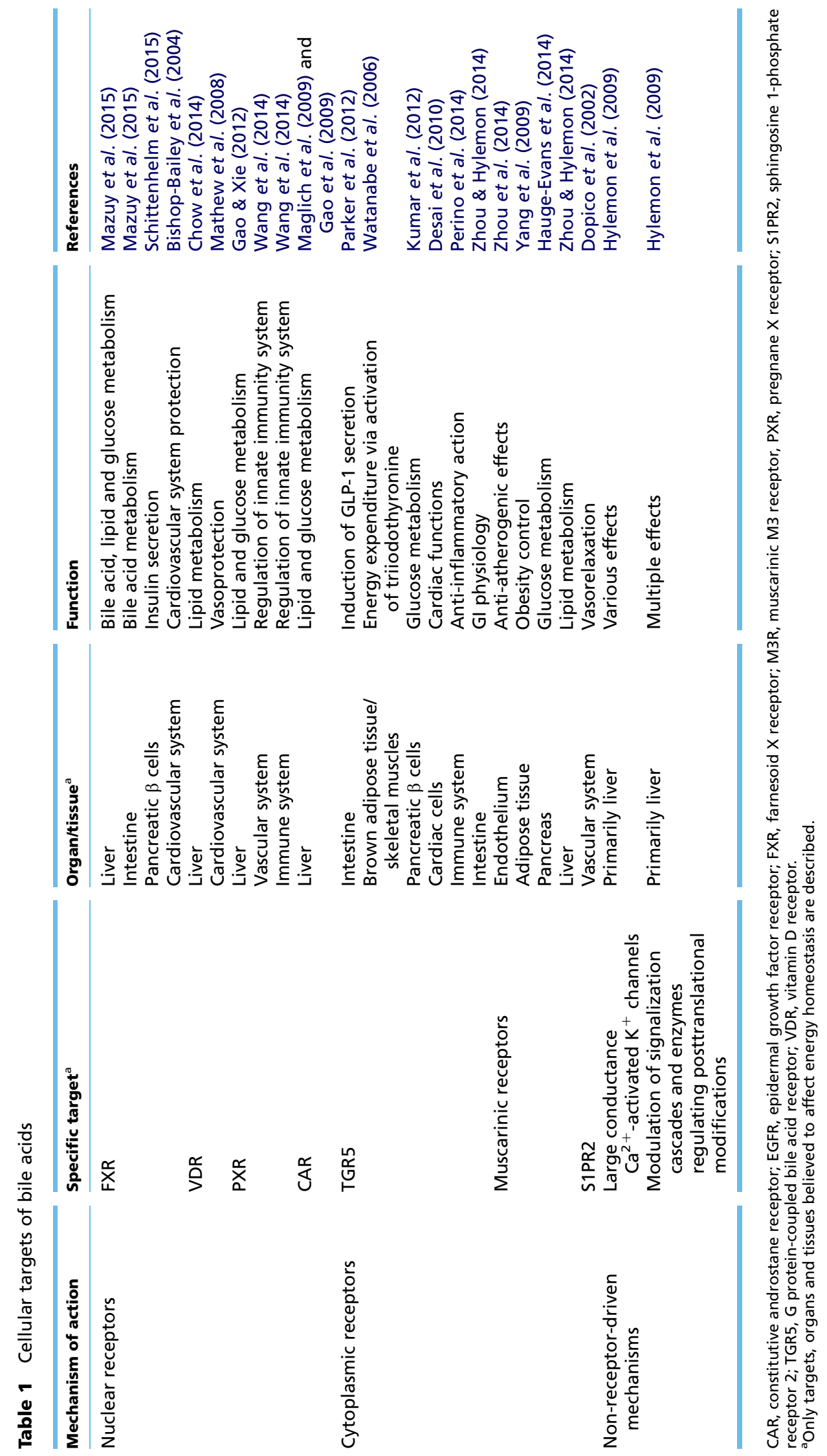
the pancreas (Hauge-Evans et al. 2014), contributing significantly to glucose homeostasis.

Interestingly, BA also activate S1PR2 in liver cells, a mechanism believed to significantly regulate hepatic lipid metabolism (Zhou \& Hylemon 2014). Sphingosine-1 phosphate, another natural ligand of S1PR2, also binds to apolipoprotein $\mathrm{M}$, whose expression is under the influence of FXR, and it plays an important role in the pathogenesis of atherosclerosis and diabetes (Ren et al. 2015). Finally, deoxycholic acid, a secondary BA, has been surprisingly demonstrated to activate the epidermal growth factor receptor (EGFR) in hepatocytes (Qiao et al. 2001). EGFR is a factor known to be associated with the progression of vascular dysfunction in diabetes (Benter et al. 2015).

Apart from receptor-mediated actions, BA exert multiple functions through additional non-receptordriven mechanisms involving the activation of large conductance $\mathrm{Ca}^{2+}$-activated $\mathrm{K}^{+}$channels that regulate arterial tone (Dopico et al. 2002), as well as many other less well-defined effects, including apoptosis, angiogenesis/ neovascularization, NO metabolism and/or inflammatory processes (for a review, see Khurana et al. (2011)). This suggests the complexity of the totality of possible biological functions of BA.

This wide array of BA-mediated functions results in the modulation of multiple signaling pathways including JNK1/2, ERK1/2 or AKT1/2, with many possible biochemical, pathophysiological and clinical consequences (Hylemon et al. 2009). BA (particularly UDCA) have been reported to even modulate the miR-34a/sirtuin1/p53 proapoptotic pathway in non-alcoholic fatty liver disease (NAFLD; Castro et al. 2013). It also modulates sirtuin 1, a histone deacetylase, which is an important sensor in regulating energy homeostasis (Li 2013) as well as in diabetes pathophysiology (Kitada \& Koya 2013). Indeed, BA, via multiple transcriptional cofactors such sirtuin 1 or SHP, have been suggested to behave as epigenomic cofactors affecting the posttranslational modification of histones (Kemper 2011, Smith et al. 2013), with deep impacts on the possible pathophysiological consequences. Indeed, BA-induced phosphorylation of SHP has been demonstrated to posttranslationally regulate hepatic metabolic genes (Seok et al. 2013). BA also inhibit lysinespecific histone demethylase 1 (LD1) (Kim et al. 2015), an enzyme playing an important role in adipogenesis (Musri et al. 2010) as well as in the development of diabetes (Brasacchio et al. 2009). Furthermore, BA have been shown to be involved in the posttranscriptional modification of
HMG-CoA reductase, a rate-limiting gene in cholesterol biosynthesis (Duckworth et al. 1991).

BA have also been shown to have potent immunosuppressive effects (Sipka \& Bruckner 2014). Obesity is associated with a chronic, low-grade inflammation (termed metabolic inflammation), which is an important contributor to the initiation and progression of NAFLD, insulin resistance, T2DM and atherosclerosis (Gregor \& Hotamisligil 2011). Thus, BA may also exert their potential anti-obesity actions via these anti-inflammatory mechanisms.

\section{BA, gut microbiota and diabetes}

Recently published data strongly suggests an important role of the gut microbiota in the development of obesity and NAFLD (Park et al. 2013). Gut microbiota cover more than 2000 species of commensal bacteria (Neish 2009), but only the recent progress in molecular techniques has revealed the vast diversity of gut microbiota, with Firmicutes and Bacteroidetes being the predominant bacterial phyla (Neish 2009).

Animal studies have proven that colonization of lean germ-free mice with the cecal microbiota of obese counterparts increases hepatic triacylglycerol accumulation, most likely through an increase in short-chain fatty acid (SCFA) fermentation in the intestinal lumen, leading to the stimulation of de novo synthesis of hepatic triacylglycerols (Backhed et al. 2004). Indeed, the gut microbiota of obese humans have a higher proportion of energy-harvesting Firmicutes bacteria, which is believed to increase the energy yield from the intestinal contents and accelerate fat accumulation in the human body (Turnbaugh et al. 2006). In fact, the ratio between the Firmicutes and Bacteroidetes phyla is important for SCFA production and is linked to obesity (Fernandes et al. 2014). These recent observations are also the rationale for several clinical trials recently initiated to treat obesity, NAFLD and/or diabetes with fecal bacterial transplantation ((Vrieze et al. 2012); and www.clinicaltrials.gov, accessed Oct 31, 2015). Further support for these data is reinforced by the results of gastric bypass studies, which have shown marked changes in the gut microbiota, correlating with weight loss (Zhang et al. 2009, Furet et al. 2010, Li et al. 2011).

Besides obesity, the pathogenesis of diabetes also seems to be closely linked with gut microbiota. Based on metagenome-wide association studies, an increase in sulfate-reducing bacteria and a decrease in butyrateproducing species have been detected in T2DM (for a

Published by Bioscientifica Ltd. 
review, see Tilg \& Moschen (2014)). It should be mentioned that sulfate-reducing bacteria utilize taurine for sulfur reduction. Taurine-conjugated BA are closely associated with a Western type of diet, contrasted to glycine-conjugated BA predominance (e.g. in native African populations), which are also devoid of 'diseases of civilization' (McGarr et al. 2005). Indeed, the Western diet has been reported to induce the taurine-conjugated BA pool, with important changes to the gut microbiome (Devkota et al. 2012). In addition, expansion of the Firmicutes phyla in the gut lumen is related to the intestinal BA pool (Islam et al. 2011). The relationship between BA metabolism and the intestinal microbiome is mutual. It is not only gut bacteria that are capable of metabolizing BA, but BA also importantly influence the gut's microbiota composition. This influence is mediated through direct antimicrobial effects on gut microbes (Begley et al. 2005), via production of antimicrobial peptides mediated by activated FXR in ileocytes (Inagaki et al. 2006), or by inhibiting intestinal absorption of bacterial endotoxins (Kocsar et al. 1969, Parlesak et al. 2007). However, these potential antimicrobial effects are still poorly understood (Hofmann \& Eckmann 2006).

It is also interesting to note that gut microbiome diversity is an important factor, capable to differentiate between lean and obese human subjects (Le Chatelier et al. 2013). The gut microbiome gene richness efficiently responds to dietary interventions (Cotillard et al. 2013), suggesting promising therapeutic approaches for obese patients.

BA, besides their 'classical' lipid digestive and respective TGR5-mediated metabolic functions, may also exert many other effects within the intestinal lumen. These, in turn, affect the susceptibility to obesity, the metabolic syndrome and/or diabetes.

One of these additional mechanisms may involve BAmediated modulation of innate intestinal immunity. It has been demonstrated that activation of FXR modulated TLR4 of the intestinal myeloid cells results in antiinflammatory effects in murine models of colitis (Vavassori et al. 2009). Also, vice versa, activation of TLR $4 / 9$ on monocytes has potent modulating effects on FXR, indicating a close interplay between FXR and effectors of innate immunity (Renga et al. 2013). Although it has been proposed that these mechanisms are implicated in intestinal inflammatory diseases, it is highly likely that they can also affect energy homeostasis as well as the risks of obesity, NAFLD and diabetes. These are all conditions where TLRs are believed to play an important pathogenic role (Jia et al. 2014, Ferreira et al. 2015).
As mentioned above, both TGR5 and FXR (NR1H4) are also functionally expressed in pancreatic $\beta$-cells, where they regulate insulin secretion (Renga et al. 2010, Seyer et al. 2013). In fact, Fxr-deficient mice develop insulin resistance (Zhang et al. 2006); on the other hand, activation of FXR reverses this phenomenon in various animal models (Zhang et al. 2006, Cipriani et al. 2010). Based on these observations, FXR activation has been proposed as a promising therapeutic target for diabetic patients (Zhang et al. 2006). Indeed, treatment of patients having NAFLD and T2DM with obeticholic acid (a potent FXR agonist) has been demonstrated to increase insulin sensitivity in a recent human trial (Mudaliar et al. 2013); however, this was not confirmed in another study (Neuschwander-Tetri et al. 2015).

Furthermore, GLUT4, the main insulin-responsive glucose transporter, playing a critical role in maintaining systemic glucose homeostasis and contributing to insulin resistance, can be induced in hepatocyte- and adipocytelike cells by chenodeoxycholic acid, which is a natural FXR agonist (Shen et al. 2008). Nevertheless, BA might also exert protective effects via FXR-independent action by the suppression of hepatic fatty acid and triacylglycerol gene expression (Wu et al. 2014).

However, not all recent data are fully supportive of the concept of the beneficial effects of FXR activation on energy homeostasis. It has recently been reported that selective disruption of intestinal FXR mediates gut microbiota-associated NAFLD development via the ceramide axis, pointing out the complexity of the entirety of FXR-mediated actions (Jiang et al. 2015). Additionally, in a mouse model, it has been demonstrated that alteration of the gut microbiota can antagonize the intestinal FXR via increased production of taurine-conjugated muricholic acid (Li et al. 2013, Sayin et al. 2013). It remains to be confirmed whether human BA conjugates may also exert the same inhibitory action on intestinal FXR.

\section{BA metabolism in constipation and possible link to metabolic diseases}

The interrelationship between BA homeostasis and metabolic diseases is far more complex. For example, it is known that patients with chronic constipation have a higher risk for cardiovascular disease (Shakir et al. 2007, Salmoirago-Blotcher et al. 2011) and T2DM (Talley et al. 2003, Salmoirago-Blotcher et al. 2011). In fact, decreased fecal BA output, a phenomenon associated with chronic constipation (Abrahamsson et al. 2008, Hofmann et al. 2008), has been reported in patients with coronary

Published by Bioscientifica Ltd. 
atherosclerosis (Charach et al. 1998, 2011). Constipation not only seems to be a consequence of autonomic diabetic neuropathy (Vinik et al. 2003), but, based on the evidence discussed above, is instead a contributing factor, via impaired intestinal and hepatic BA metabolism.

\section{BA, thyroid functions and energy expenditure}

Apart from in the small intestine, TGR5 is expressed in numerous tissues and organs including the thyroid gland, brown adipose tissue, skeletal cardiac muscle, liver and pancreas (Duboc et al. 2014). This fact led to investigations of the effects of $\mathrm{BA}$ on these organs. Surprisingly, it turned out that BA-activated TGR5 in brown fat in mice (as well as in human myocytes) stimulated intracellular cAMP formation and activated type 2 iodothyronine deiodinase (D2), which is responsible for the conversion of $\mathrm{T}_{4}$ to $\mathrm{T}_{3}$, and mediated thermogenic effects of BA (Watanabe et al. 2006). This observation was also confirmed in an experimental study by da-Silva et al. (2011), who observed exactly the same effects on D2 activity and energy expenditure with tauroursodeoxycholic acid. However, these effects may be due to the modulation of intracellular pathways unrelated to TGR5 activation (Malisova et al. 2013). In fact, thermogenic effects of BA were also verified in a human study by Ockenga et al. (2012), who reported a positive association in subjects of venous BA concentrations with energy expenditure; however, this was not observed in obese subjects (Brufau et al. 2010). The effect of $\mathrm{BA}$ on thyroid function seems to be more complex. A negative association between BA and TSH levels has been reported in certain patients (Patti et al. 2009, Ockenga et al. 2012) as well as in healthy subjects (Song et al. 2015). This is most likely due to the effect of BA on TGR5 expressed in the pituitary gland (Doignon et al. 2011, Ockenga et al. 2012). Importantly, BA sequestrants have been shown to efficiently ameliorate hyperthyroidism (Shakir et al. 1993, Hagag et al. 1998, Kaykhaei et al. 2008), even in refractory patients (Sebastian-Ochoa et al. 2008, Alswat 2015, Yang et al. 2015). This effect is believed to be mediated by impaired reabsorption of thyroid hormones (de Luis et al. 2002), but is probably much more complex.

In this context, it is also interesting to note a feedback effect of TSH/thyroxine on BA production, primarily mediated by the modulation of CYP7A1 in the liver tissue (Ellis 2006, Song et al. 2015). However, not all data are conclusive, and the role of thyroid hormones in the BA biosynthetic pathway still awaits further elucidation.

\section{BA, incretins and glucose homeostasis}

Incretin hormones, specifically glucagon-like peptide 1 (GLP-1) and glucose-dependent insulinotropic peptide (GIP), are intestine-derived hormones that increase insulin secretion and decrease glucagon secretion upon stimulation by food ingestion (Holst \& Gromada 2004), thus significantly contributing to the regulation of glucose metabolism (Holst et al. 2008). A majority of patients with T2DM have a combination of reduced GLP-1 secretion and partial resistance to its effects (Nauck et al. 2011). Both of these defects contribute to impairments of glucose metabolism in T2DM. Pharmacological approaches, which either increase endogenous GLP-1 or use the analogues of GLP-1 with a longer half-life, are now routinely used in the treatment of T2DM (Martin et al. 2011). Glucagon-like peptide 2 (GLP-2) is another intestine-derived hormone, which, in contrast to GLP-1 and GIP, does not have incretin effects. It is an important regulator of gastric motility, gastric acid secretion and intestinal hexose transport, with enhancing effects on the barrier function of the gut epithelium (Yusta et al. 2012).

BA have been shown to directly promote GLP-1 and GLP-2 secretion in small-intestinal enteroendocrine cells through TGR5 (Parker et al. 2012). Furthermore, their effect appears to be synergistic to that of glucose (Parker et al. 2012). Studies have shown that increased BA concentrations after malabsorptive bariatric surgery procedures (details provided in the next section) correlate with peak GLP-1 levels and fasting GIP levels (Patti et al. 2009, Pournaras et al. 2012, Kohli et al. 2013a). Similar associations have also been found in some other types of surgical manipulations. Importantly, numerous experimental studies have also found a positive correlation between increased BA levels after bariatric surgery and improvements in glucose homeostasis (Penney et al. 2015).

\section{How BA contribute to the effect of bariatric surgery on energy homeostasis}

Bariatric surgery not only substantially decreases body weight, but also markedly improves glucose metabolism, frequently leading to a complete remission of diabetes, as evidenced in both experimental and clinical studies (Ashrafian et al. 2010). Nevertheless, different types of operations clearly differ in their rates of diabetes remission as well as in the timing of metabolic improvements (Dixon et al. 2012). In general, bariatric operations can be classified as restrictive procedures such as gastric banding, gastric plication and sleeve gastrectomy (LSG) - or malabsorptive

Published by Bioscientifica Ltd. 
or combined procedures (e.g. gastric bypass, biliopancreatic diversion) (O'Brien 2010). In the former group, the decreased food intake and weight loss is achieved through the restriction of the stomach size without further modifications of digestive tract anatomy (Pories 2008). In the majority of malabsorptive procedures, the stomach size is also partially restricted, and a direct connection of the stomach and the lower part of the small intestine is created, thus bypassing a significant portion of the intestine. Studies have shown that restrictive procedures do not alter circulating BA concentrations, with a majority of the studies reporting either no change of BA after gastric banding (Kohli et al. 2013a) or inconsistent results after sleeve gastrectomy (Haluzikova et al. 2013, Myronovych et al. 2014). On the contrary, malabsorptive operations such as gastric bypass, which are usually more effective toward improvements of glucose metabolism, increase circulating BA levels (Kohli et al. 2013a). Plasma BA levels have also been found to increase after ileal interposition surgery, where the ileum is repositioned distal to the duodenum (Kohli et al. 2010). This manipulation is also associated with improvement of the components of the metabolic syndrome in rats with diet-induced obesity. Furthermore, the insertion of a duodenal-jejunal bypass liner (an endoscopically implanted device that eliminates the duodenum and proximal jejunum contact with digested food) has also been found to be associated with increased BA concentration in an experimental study

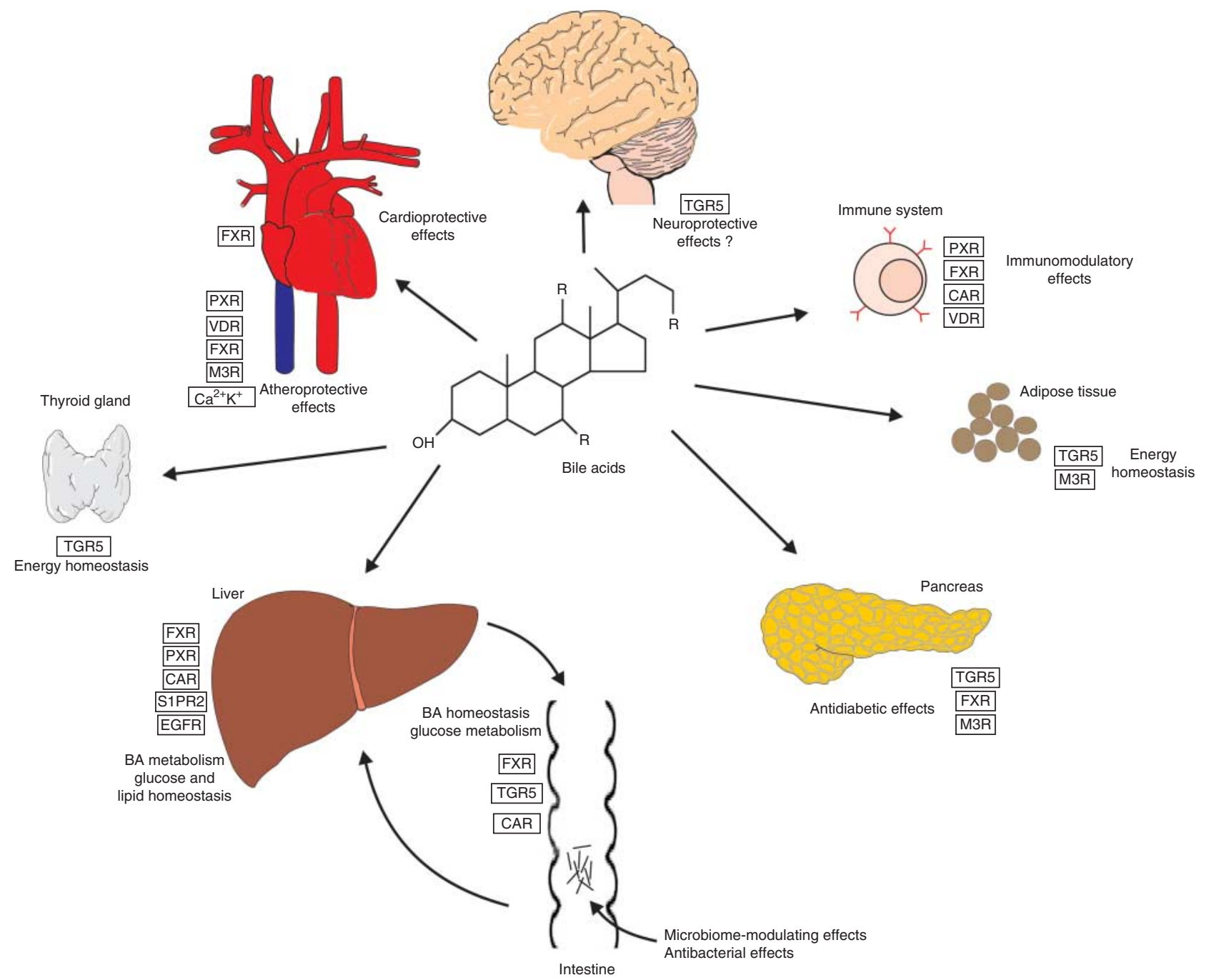

Figure 1

Receptor-mediated effects of bile acids on various tissues and organs involved in energy homeostasis. CAR, constitutive androstane receptor; EGFR, epidermal growth factor receptor; FXR, farnesoid X receptor;
$M 3 R$, muscarinic $M 3$ receptor, $P X R$, pregnane $X$ receptor; S1PR2, sphingosine 1-phosphate receptor 2; TGR5, G protein-coupled bile acid receptor; VDR, vitamin $\mathrm{D}$ receptor.

Published by Bioscientifica Ltd. 
(Habegger et al. 2014). We recently observed a similar increase in patients with type 2 diabetes 6 months after the implantation of a duodenal-jejunal bypass liner (Kavalkova P, Mraz M, Trachta P, Haluzikova D, Lacinová Z, Benes M, Vlasakova Z, Petr T, Vitek L, Pelikanova T \& Haluzik M, unpublished observations). Two experimental studies have directly demonstrated the importance of BA in post-bariatric surgery metabolic improvements by experimental diversion of bile to the distal gut, using either a catheter placed into the common bile duct of male obese rats to divert BA to the more distal jejunum (Kohli et al. $2013 b$ ) or a surgical manipulation to divert BA into the ileum (Pournaras et al. 2012) respectively. Both manipulations were associated with increased serum BA, postprandial GLP-1 secretion and improved glucose metabolism. Finally, Fxr-null mice have been shown to exhibit significantly blunted weight loss and improvements in glucose metabolism after bariatric surgery, suggesting an important role of FXR-mediated BA signaling after bariatric surgery (Ryan et al. 2014). Taken together, BA concentrations are significantly increased after malabsorptive bariatric surgery procedures. Multiple studies have shown that this increase significantly contributes to improvements in glucose homeostasis through modulations of GLP-1 secretion from the gut, changes of gut microbiota and endocrine effects of circulating BA in various organs and tissues (Fig. 1).

\section{Conclusion}

Our knowledge on the effects of BA on energy homeostasis and metabolism has dramatically expanded during the last decade. It is likely that further surprises are on the horizon, and BA will appear to have even more profound metabolic impacts. One example might be found in the observation that administration of BA sequestrants (a completely different approach from that described above) increases insulin sensitivity (Staels \& Kuipers 2007, Suzuki et al. $2007 a$ ). This most likely takes place by delaying fatty acid absorption (Suzuki et al. 2007b) and increased production of secondary BA derived from sequestrant-trapped primary BA (Harach et al. 2012), thus leading to the stimulation of GLP-1 release. The same mechanism also seems to be in play for the ASBT inhibitor elobixibat, which may provide positive metabolic side effects (in addition to positive effects on the symptoms and signs of constipation mentioned above), reducing the risk for CVD and T2DM. Indeed, decreased LDL-cholesterol and increased GLP-1 levels have been reported in patients with dyslipidemia treated with elobixibat (Rudling et al. 2015). Interestingly, the hypoglycemic effect of metformin has been suggested to be at least partly accounted for by decreased intestinal BA absorption (Carter et al. 2003). Thus, it is not surprising that colesevelam, a potent BA sequestrant, has been approved by the FDA for the treatment of T2DM. An increasing body of evidence demonstrates the important therapeutic potential of BA metabolism modulation, either through the direct regulation of a wide array of their specific receptors or as a consequence of bariatric surgical procedures. BA interaction with the intestinal microbiome is also important, although in this respect, our knowledge is still far from complete.

\section{Declaration of interest}

The authors declare that there is no conflict of interest that could be perceived as prejudicing the impartiality of the review.

\section{Funding}

This work was supported by grants PRVOUK 4102280002 from the Czech Ministry of Education, and RVO VFN64165 and NT13151-4 from the Czech Ministry of Health.

\section{References}

Abrahamsson H, Ostlund-Lindqvist AM, Nilsson R, Simren M \& Gillberg PG 2008 Altered bile acid metabolism in patients with constipationpredominant irritable bowel syndrome and functional constipation. Scandinavian Journal of Gastroenterology 43 1483-1488. (doi:10.1080/ 00365520802321212)

Alswat KA 2015 Role of cholestyramine in refractory hyperthyroidism: a case report and literature review. American Journal of Case Reports 16 486-490. (doi:10.12659/AJCR.893821)

Ashrafian H, Bueter M, Ahmed K, Suliman A, Bloom SR, Darzi A \& Athanasiou T 2010 Metabolic surgery: an evolution through bariatric animal models. Obesity Reviews 11 907-920. (doi:10.1111/j.1467-789X. 2009.00701.x)

Backhed F, Ding H, Wang T, Hooper LV, Koh GY, Nagy A, Semenkovich CF \& Gordon JI 2004 The gut microbiota as an environmental factor that regulates fat storage. PNAS 101 15718-15723. (doi:10.1073/pnas. 0407076101)

Begley M, Gahan CG \& Hill C 2005 The interaction between bacteria and bile. FEMS Microbiology Reviews 29 625-651. (doi:10.1016/j.femsre. 2004.09.003)

Benhamed F, Filhoulaud G, Caron S, Lefebvre P, Staels B \& Postic C 2014 O-GlcNAcylation links ChREBP and FXR to glucose-sensing. Frontiers in Endocrinology 5 230. (doi:10.3389/fendo.2014.00230)

Benter IF, Sarkhou F, Al-Khaldi AT, Chandrasekhar B, Attur S, Dhaunsi GS, Yousif MH \& Akhtar S 2015 The dual targeting of EGFR and ErbB2 with the inhibitor Lapatinib corrects high glucose-induced apoptosis and vascular dysfunction by opposing multiple diabetes-induced signaling changes. Journal of Drug Targeting 23 506-518. (doi:10.3109/1061186X. 2015.1057150)

Bishop-Bailey D, Walsh DT \& Warner TD 2004 Expression and activation of the farnesoid $X$ receptor in the vasculature. PNAS $1013668-3673$. (doi:10.1073/pnas.0400046101)

Brasacchio D, Okabe J, Tikellis C, Balcerczyk A, George P, Baker EK, Calkin AC, Brownlee M, Cooper ME \& El-Osta A 2009 Hyperglycemia

Published by Bioscientifica Ltd 
induces a dynamic cooperativity of histone methylase and demethylase enzymes associated with gene-activating epigenetic marks that coexist on the lysine tail. Diabetes 58 1229-1236. (doi:10.2337/db08-1666)

Brufau G, Bahr MJ, Staels B, Claudel T, Ockenga J, Boker KH, Murphy EJ, Prado K, Stellaard F, Manns MP et al. 2010 Plasma bile acids are not associated with energy metabolism in humans. Nutrition and Metabolism 7 73. (doi:10.1186/1743-7075-7-73)

Carter D, Howlett HC, Wiernsperger NF \& Bailey CJ 2003 Differential effects of metformin on bile salt absorption from the jejunum and ileum. Diabetes, Obesity and Metabolism 5 120-125. (doi:10.1046/j.1463-1326. 2003.00252.x)

Castro RE, Ferreira DM, Afonso MB, Borralho PM, Machado MV, Cortez-Pinto H \& Rodrigues CM 2013 miR-34a/SIRT1/p53 is suppressed by ursodeoxycholic acid in the rat liver and activated by disease severity in human non-alcoholic fatty liver disease. Journal of Hepatology $\mathbf{5 8}$ 119-125. (doi:10.1016/j.jhep.2012.08.008)

Charach G, Rabinovich PD, Konikoff FM, Grosskopf I, Weintraub MS \& Gilat T 1998 Decreased fecal bile acid output in patients with coronary atherosclerosis. Journal of Medicine 29 125-136.

Charach G, Grosskopf I, Rabinovich A, Shochat M, Weintraub M \& Rabinovich P 2011 The association of bile acid excretion and atherosclerotic coronary artery disease. Therapeutic Advances in Gastroenterology 4 95-101. (doi:10.1177/1756283X10388682)

Chiang JY 2009 Bile acids: regulation of synthesis. Journal of Lipid Research 50 1955-1966. (doi:10.1194/jlr.R900010-JLR200)

Chow EC, Magomedova L, Quach HP, Patel R, Durk MR, Fan J, Maeng HJ, Irondi K, Anakk S, Moore DD et al. 2014 Vitamin D receptor activation down-regulates the small heterodimer partner and increases CYP7A1 to lower cholesterol. Gastroenterology 146 1048-1059. (doi:10.1053/ j.gastro.2013.12.027)

Cipriani S, Mencarelli A, Palladino G \& Fiorucci S 2010 FXR activation reverses insulin resistance and lipid abnormalities and protects against liver steatosis in Zucker (fa/fa) obese rats. Journal of Lipid Research $\mathbf{5 1}$ 771-784. (doi:10.1194/jlr.M001602)

Cotillard A, Kennedy SP, Kong LC, Prifti E, Pons N, Le Chatelier E, Almeida M, Quinquis B, Levenez F, Galleron N et al. 2013 Dietary intervention impact on gut microbial gene richness. Nature $\mathbf{5 0 0}$ 585-588. (doi:10.1038/nature12480)

Desai MS, Shabier Z, Taylor M, Lam F, Thevananther S, Kosters A \& Karpen SJ 2010 Hypertrophic cardiomyopathy and dysregulation of cardiac energetics in a mouse model of biliary fibrosis. Hepatology $\mathbf{5 1}$ 2097-2107. (doi:10.1002/hep.23585)

Devkota S, Wang Y, Musch MW, Leone V, Fehlner-Peach H, Nadimpalli A, Antonopoulos DA, Jabri B \& Chang EB 2012 Dietary-fat-induced taurocholic acid promotes pathobiont expansion and colitis in Il10 - / - mice. Nature 487 104-108. (doi:10.1038/nature11225)

Dixon JB, le Roux CW, Rubino F \& Zimmet P 2012 Bariatric surgery for type 2 diabetes. Lancet 379 2300-2311. (doi:10.1016/S0140-6736 (12)60401-2)

Doignon I, Julien B, Serriere-Lanneau V, Garcin I, Alonso G, Nicou A, Monnet F, Gigou M, Humbert L, Rainteau D et al. 2011 Immediate neuroendocrine signaling after partial hepatectomy through acute portal hyperpressure and cholestasis. Journal of Hepatology $\mathbf{5 4} 481-488$. (doi:10.1016/j.jhep.2010.07.012)

Dopico AM, Walsh JV Jr \& Singer JJ 2002 Natural bile acids and synthetic analogues modulate large conductance $\mathrm{Ca}^{2+}$-activated $\mathrm{K}^{+}$(BKCa) channel activity in smooth muscle cells. Journal of General Physiology 119 251-273. (doi:10.1085/jgp.20028537)

Duboc H, Tache Y \& Hofmann AF 2014 The bile acid TGR5 membrane receptor: from basic research to clinical application. Digestive and Liver Disease 46 302-312. (doi:10.1016/j.dld.2013.10.021)

Duckworth PF, Vlahcevic ZR, Studer EJ, Gurley EC, Heuman DM, Beg ZH \& Hylemon PB 1991 Effect of hydrophobic bile acids on 3-hydroxy-3methylglutaryl-coenzyme A reductase activity and mRNA levels in the rat. Journal of Biochemical Chemistry 266 9413-9418.
Ellis EC 2006 Suppression of bile acid synthesis by thyroid hormone in primary human hepatocytes. World Journal of Gastroenterology 12 4640-4645. (doi:10.3748/wjg.v12.i29.4640)

Fernandes J, Su W, Rahat-Rozenbloom S, Wolever TM \& Comelli EM 2014 Adiposity, gut microbiota and faecal short chain fatty acids are linked in adult humans. Nutrition \& Diabetes 4 e121. (doi:10.1038/nutd. 2014.23)

Ferreira DF, Fiamoncini J, Prist IH, Ariga SK, de Souza HP \& de Lima TM 2015 Novel role of TLR4 in NAFLD development: modulation of metabolic enzymes expression. Biochimica Biophysica Acta 1851 1353-1359. (doi:10.1016/j.bbalip.2015.07.002)

Fuchs C, Claudel T \& Trauner M 2013 Bile acid-mediated control of liver triglycerides. Seminars in Liver Disease 33 330-342. (doi:10.1055/ s-0033-1358520)

Furet JP, Kong LC, Tap J, Poitou C, Basdevant A, Bouillot JL, Mariat D, Corthier G, Dore J, Henegar C et al. 2010 Differential adaptation of human gut microbiota to bariatric surgery-induced weight loss: links with metabolic and low-grade inflammation markers. Diabetes 59 3049-3057. (doi:10.2337/db10-0253)

Gao J \& Xie W 2012 Targeting xenobiotic receptors PXR and CAR for metabolic diseases. Trends in Pharmacological Sciences 33 552-558. (doi:10.1016/j.tips.2012.07.003)

Gao J, He J, Zhai Y, Wada T \& Xie W 2009 The constitutive androstane receptor is an anti-obesity nuclear receptor that improves insulin sensitivity. Journal of Biochemical Chemistry 284 25984-25992. (doi:10.1074/jbc.M109.016808)

Gregor MF \& Hotamisligil GS 2011 Inflammatory mechanisms in obesity. Annual Review of Immunology 29 415-445. (doi:10.1146/annurevimmunol-031210-101322)

Habegger KM, Al-Massadi O, Heppner KM, Myronovych A, Holland J, Berger J, Yi CX, Gao Y, Lehti M, Ottaway N et al. 2014 Duodenal nutrient exclusion improves metabolic syndrome and stimulates villus hyperplasia. Gut 63 1238-1246. (doi:10.1136/gutjnl-2013304583)

Hagag P, Nissenbaum H \& Weiss M 1998 Role of colestipol in the treatment of hyperthyroidism. Journal of Endocrinological Investigation 21 725-731. (doi:10.1007/BF03348036)

Haluzikova D, Lacinova Z, Kavalkova P, Drapalova J, Krizova J, Bartlova M, Mraz M, Petr T, Vitek L, Kasalicky M et al. 2013 Laparoscopic sleeve gastrectomy differentially affects serum concentrations of FGF-19 and FGF-21 in morbidly obese subjects. Obesity 21 1335-1342. (doi:10.1002/oby.20208)

Harach T, Pols TW, Nomura M, Maida A, Watanabe M, Auwerx J \& Schoonjans K 2012 TGR5 potentiates GLP-1 secretion in response to anionic exchange resins. Scientific Reports 2 430. (doi:10.1038/ srep00430)

Hauge-Evans AC, Reers C, Kerby A, Franklin Z, Amisten S, King AJ, Hassan Z, Vilches-Flores A, Tippu Z, Persaud SJ et al. 2014 Effect of hyperglycaemia on muscarinic $\mathrm{M} 3$ receptor expression and secretory sensitivity to cholinergic receptor activation in islets. Diabetes, Obesity and Metabolism 16 947-956. (doi:10.1111/dom.12301)

Hofmann AF 1984 Chemistry and enterohepatic circulation of bile acids. Hepatology 4 4S-14S. (doi:10.1002/hep.1840040803)

Hofmann AF \& Eckmann L 2006 How bile acids confer gut mucosal protection against bacteria. PNAS 103 4333-4334. (doi:10.1073/pnas. 0600780103)

Hofmann AF, Loening-Baucke V, Lavine JE, Hagey LR, Steinbach JH, Packard CA, Griffin TL \& Chatfield DA 2008 Altered bile acid metabolism in childhood functional constipation: inactivation of secretory bile acids by sulfation in a subset of patients. Journal of Pediatric Gastroenterology and Nutrition 47 598-606. (doi:10.1097/MPG. Ob013e31816920a6)

Holst JJ \& Gromada J 2004 Role of incretin hormones in the regulation of insulin secretion in diabetic and nondiabetic humans. American Journal of Physiology-Endocrinology and Metabolism 287 E199-E206. (doi:10.1152/ajpendo.00545.2003) 
Holst JJ, Deacon CF, Vilsboll T, Krarup T \& Madsbad S 2008 Glucagon-like peptide-1, glucose homeostasis and diabetes. Trends in Molecular Medicine 14 161-168. (doi:10.1016/j.molmed.2008.01.003)

Holt JA, Luo G, Billin AN, Bisi J, McNeill YY, Kozarsky KF, Donahee M, Wang DY, Mansfield TA, Kliewer SA et al. 2003 Definition of a novel growth factor-dependent signal cascade for the suppression of bile acid biosynthesis. Genes and Development 17 1581-1591. (doi:10.1101/gad. 1083503)

Houten SM, Watanabe M \& Auwerx J 2006 Endocrine functions of bile acids. EMBO Journal 25 1419-1425. (doi:10.1038/sj.emboj.7601049)

Huang W, Ma K, Zhang J, Qatanani M, Cuvillier J, Liu J, Dong B, Huang X \& Moore DD 2006 Nuclear receptor-dependent bile acid signaling is required for normal liver regeneration. Science 312 233-236. (doi:10.1126/science.1121435)

Hylemon PB, Zhou H, Pandak WM, Ren S, Gil G \& Dent P 2009 Bile acids as regulatory molecules. Journal of Lipid Research 50 1509-1520. (doi:10.1194/jlr.R900007-JLR200)

Inagaki T, Moschetta A, Lee YK, Peng L, Zhao G, Downes M, Yu RT, Shelton JM, Richardson JA, Repa JJ et al. 2006 Regulation of antibacterial defense in the small intestine by the nuclear bile acid receptor. PNAS 103 3920-3925. (doi:10.1073/pnas.0509592103)

Islam KB, Fukiya S, Hagio M, Fujii N, Ishizuka S, Ooka T, Ogura Y, Hayashi T \& Yokota A 2011 Bile acid is a host factor that regulates the composition of the cecal microbiota in rats. Gastroenterology 141 1773-1781. (doi:10.1053/j.gastro.2011.07.046)

Jia L, Vianna CR, Fukuda M, Berglund ED, Liu C, Tao C, Sun K, Liu T, Harper MJ, Lee CE et al. 2014 Hepatocyte Toll-like receptor 4 regulates obesity-induced inflammation and insulin resistance. Nature Communications 5 3878. (doi:10.1038/ncomms4878)

Jiang C, Xie C, Li F, Zhang L, Nichols RG, Krausz KW, Cai J, Qi Y, Fang ZZ, Takahashi $\mathrm{S}$ et al. 2015 Intestinal farnesoid $\mathrm{X}$ receptor signaling promotes nonalcoholic fatty liver disease. Journal of Clinical Invesigation 125 386-402. (doi:10.1172/JCI76738)

Kaykhaei MA, Shams M, Sadegholvad A, Dabbaghmanesh MH \& Omrani GR 2008 Low doses of cholestyramine in the treatment of hyperthyroidism. Endocrine 34 52-55. (doi:10.1007/s12020-008-9107-5)

Kemper JK 2011 Regulation of FXR transcriptional activity in health and disease: emerging roles of FXR cofactors and post-translational modifications. Biochimica Biophysica Acta 1812 842-850. (doi:10.1016/j.bbadis.2010.11.011)

Kharitonenkov A, Shiyanova TL, Koester A, Ford AM, Micanovic R, Galbreath EJ, Sandusky GE, Hammond LJ, Moyers JS, Owens RA et al. 2005 FGF-21 as a novel metabolic regulator. Journal of Clinical Invesigation 115 1627-1635. (doi:10.1172/JCI23606)

Khurana S, Raufman JP \& Pallone TL 2011 Bile acids regulate cardiovascular function. Clinical and Translational Science 4 210-218. (doi:10.1111/ j.1752-8062.2011.00272.x)

Kim YC, Fang S, Byun S, Seok S, Kemper B \& Kemper JK 2015 Farnesoid X receptor-induced lysine-specific histone demethylase reduces hepatic bile acid levels and protects the liver against bile acid toxicity. Hepatology 62 220-231. (doi:10.1002/hep.27677)

Kitada M \& Koya D 2013 SIRT1 in type 2 diabetes: mechanisms and therapeutic potential. Diabetes \& Metabolism Journal 37 315-325. (doi:10.4093/dmj.2013.37.5.315)

Kocsar LT, Bertok L \& Varteresz V 1969 Effect of bile acids on the intestinal absorption of endotoxin in rats. Journal of Bacteriology $\mathbf{1 0 0}$ 220-223.

Kohli R, Kirby M, Setchell KD, Jha P, Klustaitis K, Woollett LA, Pfluger PT, Balistreri WF, Tso P, Jandacek RJ et al. 2010 Intestinal adaptation after ileal interposition surgery increases bile acid recycling and protects against obesity-related comorbidities. American Journal of PhysiologyGastrointestinal and Liver Physiology 299 G652-G660. (doi:10.1152/ ajpgi.00221.2010)

Kohli R, Bradley D, Setchell KD, Eagon JC, Abumrad N \& Klein S $2013 a$ Weight loss induced by Roux-en-Y gastric bypass but not laparoscopic adjustable gastric banding increases circulating bile acids. Journal of
Clinical Endocrinology and Metabolism 98 E708-E712. (doi:10.1210/ jc.2012-3736)

Kohli R, Setchell KD, Kirby M, Myronovych A, Ryan KK, Ibrahim SH, Berger J, Smith K, Toure M, Woods SC et al. 2013b A surgical model in male obese rats uncovers protective effects of bile acids post-bariatric surgery. Endocrinology 154 2341-2351. (doi:10.1210/en.2012-2069)

Kumar DP, Rajagopal S, Mahavadi S, Mirshahi F, Grider JR, Murthy KS \& Sanyal AJ 2012 Activation of transmembrane bile acid receptor TGR5 stimulates insulin secretion in pancreatic $\beta$ cells. Biochemical and Biophysical Research Communications 427 600-605. (doi:10.1016/j.bbrc. 2012.09.104)

Le Chatelier E, Nielsen T, Qin J, Prifti E, Hildebrand F, Falony G, Almeida M, Arumugam M, Batto JM, Kennedy S et al. 2013 Richness of human gut microbiome correlates with metabolic markers. Nature 500 541-546. (doi:10.1038/nature12506)

Lenicek M, Duricova D, Komarek V, Gabrysova B, Lukas M, Smerhovsky Z \& Vitek L 2011 Bile acid malabsorption in inflammatory bowel disease: assessment by serum markers. Inflammatory Bowel Diseases 17 1322-1327. (doi:10.1002/ibd.21502)

Li X 2013 SIRT1 and energy metabolism. Acta Biochimica et Biophysica Sinica 45 51-60. (doi:10.1093/abbs/gms108)

Li T \& Chiang JY 2014 Bile acid signaling in metabolic disease and drug therapy. Pharmacological Review 66 948-983. (doi:10.1124/pr.113.008201)

Li JV, Ashrafian H, Bueter M, Kinross J, Sands C, le Roux CW, Bloom SR, Darzi A, Athanasiou T, Marchesi JR et al. 2011 Metabolic surgery profoundly influences gut microbial-host metabolic cross-talk. Gut 60 1214-1223. (doi:10.1136/gut.2010.234708)

Li F, Jiang C, Krausz KW, Li Y, Albert I, Hao H, Fabre KM, Mitchell JB, Patterson AD \& Gonzalez FJ 2013 Microbiome remodelling leads to inhibition of intestinal farnesoid $\mathrm{X}$ receptor signalling and decreased obesity. Nature Communications 4 2384. (doi:10.1038/ncomms3384)

de Luis DA, Duenas A, Martin J, Abad L, Cuellar L \& Aller R 2002 Light symptoms following a high-dose intentional L-thyroxine ingestion treated with cholestyramine. Hormone Research 57 61-63. (doi:10.1159/ 000057950)

Maglich JM, Watson J, McMillen PJ, Goodwin B, Willson TM \& Moore JT 2004 The nuclear receptor CAR is a regulator of thyroid hormone metabolism during caloric restriction. Journal of Biochemical Chemistry 279 19832-19838. (doi:10.1074/jbc.M313601200)

Maglich JM, Lobe DC \& Moore JT 2009 The nuclear receptor CAR (NR1I3) regulates serum triglyceride levels under conditions of metabolic stress. Journal of Lipid Research 50 439-445. (doi:10.1194/jlr. M800226-JLR200)

Malisova L, Kovacova Z, Koc M, Kracmerova J, Stich V \& Rossmeislova L 2013 Ursodeoxycholic acid but not tauroursodeoxycholic acid inhibits proliferation and differentiation of human subcutaneous adipocytes. PLOS ONE 8 e82086. (doi:10.1371/journal.pone.0082086)

Martin JH, Deacon CF, Gorrell MD \& Prins JB 2011 Incretin-based therapies-review of the physiology, pharmacology and emerging clinical experience. Internal Medicine Journal 41 299-307. (doi:10.1111/j.1445-5994.2011.02439.x)

Mathew S, Lund RJ, Chaudhary LR, Geurs T \& Hruska KA 2008 Vitamin D receptor activators can protect against vascular calcification. Journal of the American Society of Nephrology 19 1509-1519. (doi:10.1681/ASN. 2007080902)

Mazuy C, Helleboid A, Staels B \& Lefebvre P 2015 Nuclear bile acid signaling through the farnesoid $\mathrm{X}$ receptor. Cellular and Molecular Life Sciences 72 1631-1650. (doi:10.1007/s00018-014-1805-y)

McGarr SE, Ridlon JM \& Hylemon PB 2005 Diet, anaerobic bacterial metabolism, and colon cancer: a review of the literature. Journal of Clinical Gastroenterology 39 98-109.

Modica S, Gadaleta RM \& Moschetta A 2010 Deciphering the nuclear bile acid receptor FXR paradigm. Nuclear Receptor Signaling 8 e005. (doi:10.1621/nrs.08005)

Mudaliar S, Henry RR, Sanyal AJ, Morrow L, Marschall HU, Kipnes M, Adorini L, Sciacca CI, Clopton P, Castelloe E et al. 2013 Efficacy and

Published by Bioscientifica Ltd. 
safety of the farnesoid $\mathrm{X}$ receptor agonist obeticholic acid in patients with type 2 diabetes and nonalcoholic fatty liver disease. Gastroenterology 145 574-582. (doi:10.1053/j.gastro.2013.05.042)

Musri MM, Carmona MC, Hanzu FA, Kaliman P, Gomis R \& Parrizas M 2010 Histone demethylase LSD1 regulates adipogenesis. Journal of Biochemical Chemistry 285 30034-30041. (doi:10.1074/jbc.M110.151209)

Myronovych A, Kirby M, Ryan KK, Zhang W, Jha P, Setchell KD, Dexheimer PJ, Aronow B, Seeley RJ \& Kohli R 2014 Vertical sleeve gastrectomy reduces hepatic steatosis while increasing serum bile acids in a weight-loss-independent manner. Obesity 22 390-400. (doi:10.1002/oby.20548)

Nauck MA, Vardarli I, Deacon CF, Holst JJ \& Meier JJ 2011 Secretion of glucagon-like peptide-1 (GLP-1) in type 2 diabetes: what is up, what is down? Diabetologia 54 10-18. (doi:10.1007/s00125-010-1896-4)

Neish AS 2009 Microbes in gastrointestinal health and disease. Gastroenterology 136 65-80. (doi:10.1053/j.gastro.2008.10.080)

Neuschwander-Tetri BA, Loomba R, Sanyal AJ, Lavine JE, Van Natta ML, Abdelmalek MF, Chalasani N, Dasarathy S, Diehl AM, Hameed B et al. 2015 Farnesoid X nuclear receptor ligand obeticholic acid for non-cirrhotic, non-alcoholic steatohepatitis (FLINT): a multicentre, randomised, placebo-controlled trial. Lancet 385 956-965. (doi:10.1016/S0140-6736(14)61933-4)

O'Brien PE 2010 Bariatric surgery: mechanisms, indications and outcomes. Journal of Gastroenterology and Hepatology 25 1358-1365. (doi:10.1111/ j.1440-1746.2010.06391.x)

Ockenga J, Valentini L, Schuetz T, Wohlgemuth F, Glaeser S, Omar A, Kasim E, duPlessis D, Featherstone K, Davis JR et al. 2012 Plasma bile acids are associated with energy expenditure and thyroid function in humans. Journal of Clinical Endocrinology and Metabolism 97 535-542. (doi:10.1210/jc.2011-2329)

Park JS, Seo JH \& Youn HS 2013 Gut microbiota and clinical disease: obesity and nonalcoholic Fatty liver disease. Pediatric Gastroenterology, Hepatology and Nutrition 16 22-27. (doi:10.5223/pghn.2013.16.1.22)

Parker HE, Wallis K, le Roux CW, Wong KY, Reimann F \& Gribble FM 2012 Molecular mechanisms underlying bile acid-stimulated glucagon-like peptide-1 secretion. British Journal of Pharmacology 165 414-423. (doi:10.1111/j.1476-5381.2011.01561.x)

Parlesak A, Schaeckeler S, Moser L \& Bode C 2007 Conjugated primary bile salts reduce permeability of endotoxin through intestinal epithelial cells and synergize with phosphatidylcholine in suppression of inflammatory cytokine production. Critical Care Medicine $\mathbf{3 5}$ 2367-2374. (doi:10.1097/01.CCM.0000284586.84952.FB)

Patti ME, Houten SM, Bianco AC, Bernier R, Larsen PR, Holst JJ, Badman MK, Maratos-Flier E, Mun EC, Pihlajamaki J et al. 2009 Serum bile acids are higher in humans with prior gastric bypass: potential contribution to improved glucose and lipid metabolism. Obesity 17 1671-1677. (doi:10.1038/oby.2009.102)

Penney NC, Kinross J, Newton RC \& Purkayastha S 2015 The role of bile acids in reducing the metabolic complications of obesity after bariatric surgery: a systematic review. International Journal of Obesity 39 1565-1574. (doi:10.1038/ijo.2015.115)

Perino A, Pols TW, Nomura M, Stein S, Pellicciari R \& Schoonjans K 2014 TGR5 reduces macrophage migration through mTOR-induced C/EBP $\beta$ differential translation. Journal of Clinical Invesigation 124 5424-5436. (doi:10.1172/JCI76289)

Pories WJ 2008 Bariatric surgery: risks and rewards. Journal of Clinical Endocrinology and Metabolism 93 S89-S96. (doi:10.1210/jc.2008-1641)

Potthoff MJ, Kliewer SA \& Mangelsdorf DJ 2012 Endocrine fibroblast growth factors 15/19 and 21: from feast to famine. Genes and Development 26 312-324. (doi:10.1101/gad.184788.111)

Pournaras DJ, Glicksman C, Vincent RP, Kuganolipava S, Alaghband-Zadeh J, Mahon D, Bekker JH, Ghatei MA, Bloom SR, Walters JR et al. 2012 The role of bile after Roux-en-Y gastric bypass in promoting weight loss and improving glycaemic control. Endocrinology 153 3613-3619. (doi:10.1210/en.2011-2145)
Qi Y, Jiang C, Cheng J, Krausz KW, Li T, Ferrell JM, Gonzalez FJ \& Chiang JY 2015 Bile acid signaling in lipid metabolism: metabolomic and lipidomic analysis of lipid and bile acid markers linked to anti-obesity and anti-diabetes in mice. Biochimica Biophysica Acta 1851 19-29. (doi:10.1016/j.bbalip.2014.04.008)

Qiao L, Studer E, Leach K, McKinstry R, Gupta S, Decker R, Kukreja R, Valerie K, Nagarkatti P, El Deiry W et al. 2001 Deoxycholic acid (DCA) causes ligand-independent activation of epidermal growth factor receptor (EGFR) and FAS receptor in primary hepatocytes: Inhibition of EGFR/mitogen-activated protein kinase-signaling module enhances DCA-induced apoptosis. Molecular Biology of the Cell 12 2629-2645. (doi:10.1091/mbc.12.9.2629)

Raufman JP, Cheng K \& Zimniak P 2003 Activation of muscarinic receptor signaling by bile acids: physiological and medical implications. Digestive Diseases and Sciences 48 1431-1444. (doi:10.1023/A:1024733500950)

Ren K, Tang ZL, Jiang Y, Tan YM \& Yi GH 2015 Apolipoprotein M. Clinical Chemica Acta 446 21-29. (doi:10.1016/j.cca.2015.03.038)

Renga B, Mencarelli A, Vavassori P, Brancaleone V \& Fiorucci S 2010 The bile acid sensor FXR regulates insulin transcription and secretion. Biochimica Biophysica Acta 1802 363-372. (doi:10.1016/j.bbadis.2010. 01.002)

Renga B, Mencarelli A, Cipriani S, D'Amore C, Carino A, Bruno A, Francisci D, Zampella A, Distrutti E \& Fiorucci S 2013 The bile acid sensor FXR is required for immune-regulatory activities of TLR-9 in intestinal inflammation. PLOS ONE 8 e54472. (doi:10.1371/journal. pone.0054472)

Ridlon JM, Kang DJ, Hylemon PB \& Bajaj JS 2014 Bile acids and the gut microbiome. Current Opinion in Gastroenterology 30 332-338. (doi:10.1097/MOG.0000000000000057)

Rudling M, Camilleri M, Graffner H, Holst JJ \& Rikner L 2015 Specific inhibition of bile acid transport alters plasma lipids and GLP-1. BMC Cardiovascular Disorders 15 75. (doi:10.1186/s12872-015-0070-9)

Ryan KK, Tremaroli V, Clemmensen C, Kovatcheva-Datchary P, Myronovych A, Karns R, Wilson-Perez HE, Sandoval DA, Kohli R, Backhed F et al. 2014 FXR is a molecular target for the effects of vertical sleeve gastrectomy. Nature 509 183-188. (doi:10.1038/nature13135)

Salmoirago-Blotcher E, Crawford S, Jackson E, Ockene J \& Ockene I 2011 Constipation and risk of cardiovascular disease among postmenopausal women. American Journal of Medicine 124 714-723. (doi:10.1016/j. amjmed.2011.03.026)

Sayin SI, Wahlstrom A, Felin J, Jantti S, Marschall HU, Bamberg K, Angelin B, Hyotylainen T, Oresic M \& Backhed F 2013 Gut microbiota regulates bile acid metabolism by reducing the levels of tauro- $\beta$-muricholic acid, a naturally occurring FXR antagonist. Cell Metabolism 17 225-235. (doi:10.1016/j.cmet.2013.01.003)

Schittenhelm B, Wagner R, Kahny V, Peter A, Krippeit-Drews P, Dufer M \& Drews G 2015 Role of FXR in $\beta$-cells of lean and obese mice. Endocrinology 156 1263-1271. (doi:10.1210/en.2014-1751)

Sebastian-Ochoa A, Quesada-Charneco M, Fernandez-Garcia D, Reyes-Garcia R, Rozas-Moreno P \& Escobar-Jimenez F 2008 Dramatic response to cholestyramine in a patient with Graves' disease resistant to conventional therapy. Thyroid 18 1115-1117. (doi:10.1089/thy. 2008.0094)

Seok S, Kanamaluru D, Xiao Z, Ryerson D, Choi SE, Suino-Powell K, Xu HE, Veenstra TD \& Kemper JK 2013 Bile acid signal-induced phosphorylation of small heterodimer partner by protein kinase $C \zeta$ is critical for epigenomic regulation of liver metabolic genes. Journal of Biochemical Chemistry 288 23252-23263. (doi:10.1074/jbc.M113.452037)

Seyer P, Vallois D, Poitry-Yamate C, Schutz F, Metref S, Tarussio D, Maechler P, Staels B, Lanz B, Grueter R et al. 2013 Hepatic glucose sensing is required to preserve $\beta$ cell glucose competence. Journal of Clinical Invesigation 123 1662-1676. (doi:10.1172/JCI65538)

Shakir KM, Michaels RD, Hays JH \& Potter BB 1993 The use of bile acid sequestrants to lower serum thyroid hormones in iatrogenic hyperthyroidism. Annals of Internal Medicine 118 112-113. (doi:10.7326/0003-4819-118-2-199301150-00006) 
Shakir YA, Samsioe G, Khatibi EA, Nyberg P, Lidfeldt J, Agardh CD \& Nerbrand C 2007 Health hazards in middle-aged women with cardiovascular disease: a case-control study of swedish women. The women's health in the Lund area (WHILA) study. Journal of Women's Health 16 406-414. (doi:10.1089/jwh.2006.0056)

Shen H, Zhang Y, Ding H, Wang X, Chen L, Jiang H \& Shen X 2008 Farnesoid X receptor induces GLUT4 expression through FXR response element in the GLUT4 promoter. Cellular Physiology and Biochemistry 22 1-14. (doi:10.1159/000149779)

da-Silva WS, Ribich S, Arrojo e Drigo R, Castillo M, Patti ME \& Bianco AC 2011 The chemical chaperones tauroursodeoxycholic and 4-phenylbutyric acid accelerate thyroid hormone activation and energy expenditure. FEBS Letter 585 539-544. (doi:10.1016/j.febslet.2010.12.044)

Sipka S \& Bruckner G 2014 The immunomodulatory role of bile acids. International Archives of Allergy and Immunology 165 1-8. (doi:10.1159/ 000366100)

Smith Z, Ryerson D \& Kemper JK 2013 Epigenomic regulation of bile acid metabolism: emerging role of transcriptional cofactors. Molecular Cell Endocrinology 368 59-70. (doi:10.1016/j.mce.2012.04.008)

Song Y, Xu C, Shao S, Liu J, Xing W, Xu J, Qin C, Li C, Hu B, Yi S et al. 2015 Thyroid-stimulating hormone regulates hepatic bile acid homeostasis via SREBP-2/HNF-4 $\alpha$ /CYP7A1 axis. Journal of Hepatology 62 1171-1179. (doi:10.1016/j.jhep.2014.12.006)

Staels B \& Kuipers F 2007 Bile acid sequestrants and the treatment of type 2 diabetes mellitus. Drugs 67 1383-1392. (doi:10.2165/00003495200767100-00001)

Suzuki T, Oba K, Futami-Suda S, Suzuki K, Ouchi M, Igari Y, Matsumura N, Watanabe K, Kigawa Y \& Nakano H 2007 a Effects of colestimide on blood glucose-lowering activity and body weight in patients with type 2 diabetes and hypercholesterolemia. Journal of Nippon Medical School $\mathbf{7 4}$ 81-84. (doi:10.1272/jnms.74.81)

Suzuki T, Oba K, Igari Y, Matsumura N, Watanabe K, Futami-Suda S, Yasuoka H, Ouchi M, Suzuki K, Kigawa Y et al. 2007b Colestimide lowers plasma glucose levels and increases plasma glucagon-like peptide-1 (7-36) levels in patients with type 2 diabetes mellitus complicated by hypercholesterolemia. Journal of Nippon Medical School 74 338-343. (doi:10.1272/jnms.74.338)

Talley NJ, Jones M, Nuyts G \& Dubois D 2003 Risk factors for chronic constipation based on a general practice sample. American Journal of Gastroenterology 98 1107-1111. (doi:10.1111/j.1572-0241.2003.07465.x)

Thomas C, Gioiello A, Noriega L, Strehle A, Oury J, Rizzo G, Macchiarulo A, Yamamoto H, Mataki C, Pruzanski M et al. 2009 TGR5-mediated bile acid sensing controls glucose homeostasis. Cell Metabolism 10 167-177. (doi:10.1016/j.cmet.2009.08.001)

Tilg H \& Moschen AR 2014 Microbiota and diabetes: an evolving relationship. Gut 63 1513-1521. (doi:10.1136/gutjnl-2014-306928)

Tomlinson E, Fu L, John L, Hultgren B, Huang X, Renz M, Stephan JP, Tsai SP, Powell-Braxton L, French D et al. 2002 Transgenic mice expressing human fibroblast growth factor-19 display increased metabolic rate and decreased adiposity. Endocrinology 143 1741-1747. (doi:10.1210/endo.143.5.8850)

Turnbaugh PJ, Ley RE, Mahowald MA, Magrini V, Mardis ER \& Gordon JI 2006 An obesity-associated gut microbiome with increased capacity for energy harvest. Nature 444 1027-1031. (doi:10.1038/nature05414)

Vavassori P, Mencarelli A, Renga B, Distrutti E \& Fiorucci S 2009 The bile acid receptor FXR is a modulator of intestinal innate immunity. Journal of Immunology 183 6251-6261. (doi:10.4049/jimmunol. 0803978)

Vinik AI, Maser RE, Mitchell BD \& Freeman R 2003 Diabetic autonomic neuropathy. Diabetes Care 26 1553-1579. (doi:10.2337/diacare.26. 5.1553)
Vítek L 2015 Bile acid malabsorption in inflammatory bowel disease. Inflammatory Bowel Diseases 21 476-483. (doi:10.1097/MIB. 0000000000000193)

Vrieze A, Schopman JE, Admiraal WM, Soeters MR, Nieuwdorp M, Verberne HJ \& Holleman F 2012 Fasting and postprandial activity of brown adipose tissue in healthy men. Journal of Nuclear Medicine 53 1407-1410. (doi:10.2967/jnumed.111.100701)

Wang X, Fang X, Zhou J, Chen Z, Zhao B, Xiao L, Liu A, Li YS, Shyy JY, Guan Y et al. 2013 Shear stress activation of nuclear receptor PXR in endothelial detoxification. PNAS 110 13174-13179. (doi:10.1073/pnas. 1312065110)

Wang S, Lei T, Zhang K, Zhao W, Fang L, Lai B, Han J, Xiao L \& Wang N 2014 Xenobiotic pregnane $\mathrm{X}$ receptor (PXR) regulates innate immunity via activation of NLRP3 inflammasome in vascular endothelial cells. Journal of Biochemical Chemistry 289 30075-30081. (doi:10.1074/jbc. M114.578781)

Watanabe M, Houten SM, Mataki C, Christoffolete MA, Kim BW, Sato H, Messaddeq N, Harney JW, Ezaki O, Kodama T et al. 2006 Bile acids induce energy expenditure by promoting intracellular thyroid hormone activation. Nature 439 484-489. (doi:10.1038/nature04330)

Wu W, Liu X, Peng X, Xue R, Ji L, Shen X, Chen S, Gu J \& Zhang S 2014 Bile acids override steatosis in farnesoid $X$ receptor deficient mice in a model of non-alcoholic steatohepatitis. Biochemical and Biophysical Research Communications 448 50-55. (doi:10.1016/j.bbrc.2014.04.048)

Yang TT, Chang CK, Tsao CW, Hsu YM, Hsu CT \& Cheng JT 2009 Activation of muscarinic M-3 receptor may decrease glucose uptake and lipolysis in adipose tissue of rats. Neuroscience Letter 451 57-59. (doi:10.1016/j.neulet.2008.12.029)

Yang Y, Hwang S, Kim M, Lim Y, Kim MH, Lee S, Lim DJ, Kang MI \& Cha BY 2015 Refractory Graves' disease successfully cured by adjunctive cholestyramine and subsequent total thyroidectomy. Endocrinology and Metabolism [in press].

Yusta B, Holland D, Waschek JA \& Drucker DJ 2012 Intestinotrophic glucagon-like peptide-2 (GLP-2) activates intestinal gene expression and growth factor-dependent pathways independent of the vasoactive intestinal peptide gene in mice. Endocrinology 153 2623-2632. (doi:10.1210/en.2012-1069)

Zhang J, Huang W, Qatanani M, Evans RM \& Moore DD 2004 The constitutive androstane receptor and pregnane $\mathrm{X}$ receptor function coordinately to prevent bile acid-induced hepatotoxicity. Journal of Biochemical Chemistry 279 49517-49522. (doi:10.1074/jbc. M409041200)

Zhang Y, Lee FY, Barrera G, Lee H, Vales C, Gonzalez FJ, Willson TM \& Edwards PA 2006 Activation of the nuclear receptor FXR improves hyperglycemia and hyperlipidemia in diabetic mice. PNAS 103 1006-1011. (doi:10.1073/pnas.0506982103)

Zhang H, DiBaise JK, Zuccolo A, Kudrna D, Braidotti M, Yu Y, Parameswaran P, Crowell MD, Wing R, Rittmann BE et al. 2009 Human gut microbiota in obesity and after gastric bypass. PNAS 106 2365-2370. (doi:10.1073/pnas.0812600106)

Zhou H \& Hylemon PB 2014 Bile acids are nutrient signaling hormones. Steroids 86C 62-68. (doi:10.1016/j.steroids.2014.04.016)

Zhou JH, Pan ZY, Zhang YF, Cui WY, Long CL \& Wang H 2014 Stimulation of endothelial non-neuronal muscarinic receptor attenuates the progression of atherosclerosis via inhibiting endothelial cells activation. Zhongguo Ying Yong Sheng Li Xue Za Zhi 30 549-559.

Zwicker BL \& Agellon LB 2013 Transport and biological activities of bile acids. International Journal of Biochemistry \& Cell Biology 45 1389-1139. (doi:10.1016/j.biocel.2013.04.012)

Received in final form 30 December 2015

Accepted 5 January 2016

Accepted Preprint published online 5 January 2016 http://joe.endocrinology-journals.org

DOI: $10.1530 / J O E-15-0469$
(C) 2016 Society for Endocrinology Printed in Great Britain
Published by Bioscientifica Ltd 